\title{
IDENTIFIKASI FLAVONOID DAUN TEH HIJAU (Camelia sinensis L. Kuntze) SECARA REAKSI WARNA DAN KROMATOGRAFI LAPIS TIPIS
}

\author{
Afriani Kusumawati \\ Akademi Farmasi Tadulako Farma Palu \\ Email :afriani.kusumawati@yahoo.com
}

\begin{abstract}
Green tea plant (Camellia sinensis L. Kuntze) were examined in this study were taken from green tea products Cap Head Djenggot, from the area of Solo, Central Java. This plant thrives in the area of Green Tea plantation in the Solo area. For identification of the content of flavonoids in green tea leaves can be done Thin Layer Chromatography is accompanied by a color reaction.Spotting obtained detected with ammonia vapor is then observed with UV light UV $254 \mathrm{~nm}$ and 366 $\mathrm{nm}$. In observation using a $254 \mathrm{~nm}$ UV light there is a blackish brown spots on the fraction of water-chloroform, the chloroform fraction of the spots are a light green color, and the $n$-butanol fraction contained a brown patches muda.Dengan using 366 $n m$ UV rays are one dark brown spots on the fraction of water-chloroform, the chloroform fraction contained patches of light green color, and the $n$-butanol fraction contained a light brown spots. Based on data obtained from the reaction of color and Thin Layer Chromatography showed that the compound contained flavonoids in green tea leaves.
\end{abstract}

Keywords:Green tea leaves, flavonoids, thin layer chromatography

\section{PENDAHULUAN}

Teh hijau (Green Tea) memiliki banyak manfaat dari senyawa bioaktif yang terkandung didalamnya.Zat bioaktif itu disebut Flavanoid.Flavanoid itu sendiri digolongkan menjadi enam kelas yaitu flavone, flavanone, isoflavone, flavonol, flavanol dan anthocyanin. ${ }^{1}$

Penelitian tentang Teh Hijau terus dilakukan, hingga pada tahun 2004 diketahuilah secara menyeluruh adanya komponen-komponen dalam Teh Hijau sebagai antioksidan kuat, yaitu yang mampu menangkal serangan radikal bebas yang menyebabkan gangguan degenerasi pada organ-organ manusia, termasuk timbulnya berbagai jenis kanker, diantaranya di esofagus (saluran masuk makanan ke lambung), lambung, pankreas, usus, dubur, kandung kemih, prostat, bahkan juga paru-paru dan payudara. $^{2}$ 
Identifikasi flavonoid daun teh hijau (Camelia sinensis L. Kuntze) secara reaksi warna dan kromatografi lapis tipis

Selain itu, semua bagian tanaman Teh Hijau juga bisa digunakan sebagai bahan-bahan kosmetik. Dari banyaknya produk yang bisa dihasilkan dari tanaman Teh Hijau ini dapat membuktikan bahwa tanaman Teh Hijau bukan hanya bisa digunakan sebagai minuman dan obat saja, tetapi bisa juga digunakan untuk pembuatan produk-produk yang sering digunakan dalam kehidupan sehari-hari. ${ }^{1}$

Oleh karena itu, penelitian ini dilakukan untuk mengidentifikasi kandungan Flavonoid yang terdapat pada daun Teh Hijau (Camelia sinensis L. Kuntze) dengan menggunakan Kromatografi Lapis Tipis dan reaksi warna. ${ }^{3}$

\section{METODE PENELITIAN}

Bahan yang digunakan adalah Serbuk daun Teh Hijau, etanol $96 \%$, kloroform, n-butanol, serbuk magnesium, $\mathrm{HCl}$ pekat, aseton, asam borat, asam oksalat, eter, asam sitrat, lempeng silika gel, n-butanol : asam asetat : air ( $4: 1: 5 \mathrm{v} / \mathrm{v}$, fase atas).

\section{Prosedur kerja}

\section{Penyiapan bahan utama}

Daun Teh Hijau yang digunakan dalam penelitian sudah dalam keadaan kering dan berbentuk serbuk. Sehingga tidak perlu lagi dilakukan proses pengeringan. Karena serbuk daun Teh Hijau yang digunakan pada penelitian ini sudah dalam bentuk produk teh celup cap " Kepala Djenggot".

\section{Penyarian senyawa Flavonoid}

Serbuk daun Teh Hijau ditimbang sebanyak 15 gram, kemudian diekstraksi dengan menggunakan soxhlet dengan pelarut etanol $96 \%$ sebanyak $200 \mathrm{ml}$. Kemudian dipanaskan diatas penangas air dengan suhu berkisar antara $70-80 \quad \mathrm{C}$. Penyarian dihentikan setelah terjadi dua kali sirkulasi dengan menghasilkan filtrat yang berwarna hijau tua pekat. Selanjutnya filtrat yang dihasilkan tadi dipekatkan dengan menggunakan alat vakum evaporator hingga diperoleh ekstrak kental sebanyak $20 \mathrm{ml}$.

\section{Fraksinasi Flavonoid}

Ekstrak etanol ditambahkan air sebanyak $5 \mathrm{ml}$ untuk mendapatkan ekstrak etanol-air dilakukan fraksinasi dengan menggunakan pelarut non polar yaitu dengan ditambahkan kloroform sebanyak $20 \mathrm{ml}$. Kemudian dimasukkan kedalam corong pisah dan dikocok sehingga menghasilkan fraksi air-kloroform.

Fraksi air-kloroform yang diperoleh kemudian difraksinasi dengan menggunakan nbutanol.Dengan cara fraksi air- 
Identifikasi flavonoid daun teh hijau (Camelia sinensis L. Kuntze) secara reaksi warna dan kromatografi lapis tipis

kloroform ditambahkan n-butanol sebanyak $30 \mathrm{ml}$, dikocok dalam corong pisah .Fraksi yang diperoleh dari hasil pemisahan ini adalah fraksi airkloroform, fraksi kloroform dan fraksi n-butanol.

Masing-masing fraksi yang dihasilkan dipekatkan, kemudian diuji dengan menggunakan Kromatografi Lapis Tipis.

\section{Identifikasi kandungan Flavanoid masing-masing fraksi secara Kromatografi Lapis Tipis}

Pemeriksaan

kandungan

Flavanoid dilakukan pada masingmasing fraksi secara Kromatografi Lapis Tipis dengan menggunakan fase diam Silika gel dan fase gerak yang digunakan adalah n-butanol : asam asetat : air (4:1:5 v/v, fase atas). Deteksi awal bercak dilakukan dibawah sinar UV 254 nm dan 366 nm sebelum dan sesudah diuapi amonia dan disemprot dengan aluminium (III) klorida.

\section{Identifikasi warna senyawa}

\section{Flavonoid}

\section{Uji Shinoda untuk Flavonoid}

Diambil larutan percobaan dari fraksi air-kloroform, fraksi kloroform, dan fraksi n-butanol masing-masing sebanyak $1 \mathrm{ml}$, diuapkan hingga kering dan sisanya dilarutkan kembali dengan $1 \mathrm{ml}$ etanol $95 \%$. Selanjutnya ditambahkan $100 \mathrm{mg}$ logam magnesium dan $10 \mathrm{ml} \mathrm{HCl}$ pekat.Jika terjadi warna merah sampai merah ungu, menunjukkan adanya Flavonoid.

\section{Reaksi Taubeck untuk Flavanoid}

Diambil larutan percobaan dari fraksi air-kloroform, fraksi kloroform, dan fraksi n-butanol masing-masing sebanyak $1 \mathrm{ml}$, diuapkan hingga kering dan sisanya dibasahi dengan aseton, ditambahkan sedikit serbuk asam borat dan asam oksalat. Dipanaskan diatas penangas air tetapi dihindari panas yang berlebihan. Kemudian ke dalam sisa ini ditambahkan $10 \mathrm{ml}$ eter.Dilakukan pengamatan dibawah sinar UV $366 \mathrm{~nm}$ dan terjadi fluoresensi kuning.

\section{Reaksi Wilson utuk Flavonoid}

Diambil larutan percobaan dari fraksi air-kloroform, fraksi kloroform, dan fraksi n-butanol masing-masing sebanyak $1 \mathrm{ml}$, diuapkan hingga kering dan sisanya dibasahi dengan aseton, ditambahkan sedikit serbuk asam borat dan asam sitrat. Dipanaskan diatas penangas air tetapi dihindari panas yang berlebihan. Kemudian kedalam sisa ini ditambahkan $10 \mathrm{ml}$ aseton.Dilakukan pengamatan dibawah sinar UV $366 \mathrm{~nm}$ dan terjadi warna kuning tetapi tidak berfluoresensi. 
Identifikasi flavonoid daun teh hijau (Camelia sinensis L. Kuntze) secara reaksi warna dan kromatografi lapis tipis

\section{HASIL DAN PEMBAHASAN}

Penyiapan bahan utama

Daun Teh Hijau (Camelia sinensis L. Kuntze) yang digunakan pada penelitian ini merupakan suatu produk jasi yang berasal dari Solo (Jawa Tengah). Sehingga daun Teh Hijau ini tidak perlu lagi mengalami proses pembersihan, pengeringan, penyerbukan, maupun pengayakan lagi.. Karena daun Teh Hijau, pada saat proses produksi sudah tentu mengalami semua proses tersebut. Sehingga tidak perlu dilakukan proses itu lagi.

\section{Penyarian senyawa Flavonoid}

Penyarian yang dilakukan menggunakan cara soxhletasi yang dapat mengektraksi secara berkesinambungan sehingga tidak memerlukan cairan penyari yang terlalu banyak untuk mendapatkan ekstrak daun Teh Hijau yang sempurna. Karena sebagian besar senyawa Flavonoid pada tumbuhan berbentuk glikosida.Maka umumnya Flavonoid bersifat polar.Cairan penyari yang digunakan pada penelitian ini yaitu etanol $96 \%$.Etanol $96 \%$ merupakan pelarut umum, dimana sebagian besar senyawa-senyawa Flavonoid dapat tersari dari serbuk daun Teh Hijau.
Hasil penyarian diperoleh filtrat berwarna hijau tua.Kemudian filtrat dipekatkan dengan menggunakan vakum evaporator. Proses penguapan yang dilakukan pada alat vakum evaporator tersebut bertujuan untuk menguapkan sebagian pelarut etanol untuk memperoleh ekstrak yang kental. Proses ini juga sekaligus berfungsi untuk memisahkan senyawa klorofil. Sebab klorofil yang ada pada estrak tersebut dapat dipisahkan dengan adanya proses pemutaran yang kecepatannya relatif tinggi dengan menggunakan alat vakum evaporator. Jika kadar klorofil yang terkandung pada ekstrak tersebut terlalu tinggi, maka hal ini dapat menggangu proses identifikasi senyawa Flavonoid pada Kromatografi Lapis Tipis danreaksi warna.

\section{Fraksinasi Flavonoid}

Ekstrak etanol Teh Hijau yang telah dipekatkan ditambahkan dengan sedikit air lalu dilakukan fraksinasi dengan kloroform dan nbutanol.Fraksinasi ini bertujuan untuk memisahkan senyawa Flavonoid sesuai dengan tingkat kepolaran masing-masing pelarut.

Pada ekstrak etanol Teh Hijau yang ditambahkan dengan sedikit air, dan difraksinasi dengan kloroform yang menghasilkan fraksi air- 
Identifikasi flavonoid daun teh hijau (Camelia sinensis L. Kuntze) secara reaksi warna dan kromatografi lapis tipis

kloroform.Tidak terjadi pemisahan, hal ini disebabkan estrak etanol Teh Hijau dapat larut dalam air dan kloroform.

Setelah fraksi air-kloroform ditambahkan dengan n-butanol dan difraksinasi.Maka pada fraksinasi tersebut terjadi pemisahan antara fraksi kloroform dengan fraksi $n$ butanol. Sehingga proses fraksinasi tersebut menghasilkan fraksi airkloroform, fraksi kloroform, dan fraksi n-butanol.

\section{Identifikasi kandungan Flavanoid masing-masing fraksi secara Kromatografi Lapis Tipis}

Identifikasi

kandungan

Flavonoid dilakukan pada fraksi airkloroform, fraksi kloroform, dan fraksi n-butanol.Dari hasil pemeriksaan secara Kromatografi Lapis Tipis yang mengandung senyawa Flavonoid hanya terdapat pada fraksi airkloroform dan fraksi n-butanol.Hal ini dikarenakan hasil dari Kromatografi Lapis Tipis pada fraksi air-kloroform terdapat satu bercak warna coklat tua dan pada fraksi $n$-butanol terdapat satu bercak warna coklat muda.

Pada fraksi kloroform hasil yang diperoleh tidak menunjukkan adanya senyawa Flavonoid, hal ini dikarenakan bercak yang diperoleh warnanya hiaju. Identifikasi kandungan Flavonoid pada fraksi air-kloroform, fraksi kloroform, dan fraksi n-butanol dilakukan secara Kromatografi Lapis Tipis dengan menggunakan fase diam Silika gel dan fase gerak BAW/ nbutanol : Asam asetat : Air (4:1: $5 \mathrm{v} / \mathrm{v}$, fase atas).

Dari hasil analisis secara Kromatografi Lapis Tipis Fraksi nbutanol memberikan intensitas bercak yang jelas dan pemisahan yang paling baik sehingga kemungkinan kandungan Flavonoid yang paling banyak terdapat pada fraksi n-butanol. Identifikasi warna bercak dideteksi sebelum dan sesudah diuapi dengan amonia, kemudian disemprot dengan aluminium (III) klorida, setelah itu dilakukan pengamatan dibawah sinar UV $254 \mathrm{~nm}$ dan $366 \mathrm{~nm}$. Hasil identifikasi menunjukkan terdapat senyawa Flavonoid pada daun Teh Hijau.

\section{Identifikasi warna senyawa Flavonoid}

Dari masing- masing fraksi, yakni fraksi air-kloroform, fraksi kloroform, dan fraksi n-butanol diidentifikasi dengan beberapa pereaksi yaitu larutan eter, aseton dan magnesium dalam $\mathrm{HCl}$. Dari hasil reaksi warna yang dilakukan juga menunjukkan terdapat senyawa Flavonoid pada daun Teh Hijau. 
Uji daya hambat ekstrak etil asetat daun binahong (Anredera coliforlia (Ten.) Steenis) terhadap pertumbuhan bakteri Staphylococcus aureus dan Escherichia coli.

KESIMPULAN

Hasil Analisis Identifikasi

kandungan Flavanoid pada daun Teh

Hijau dapat dilakukan secara

Kromatografi Lapis Tipis yang disertai dengan reaksi warna.Bercak yang diperoleh dideteksi dengan uap amonia kemudian diamati dengan sinar UV $254 \mathrm{~nm}$ dan UV $366 \mathrm{~nm}$. Pada pengamatan dengan menggunakan sinar UV $254 \mathrm{~nm}$ terdapat satu bercak warna coklat kehitaman pada fraksi air-kloroform, pada fraksi kloroform terdapat satu bercak warna hijau muda, dan pada fraksi n-butanol terdapat satu bercak warna coklat muda.Dengan menggunakan sinar UV $366 \mathrm{~nm}$ terdapat satu bercak warna coklat tua pada fraksi air-kloroform, pada fraksi kloroform terdapat bercak warna hijau muda, dan pada fraksi n-butanol terdapat satu bercak warna coklat muda.Berdasarkan data yang diproleh dari hasil reaksi warna dan Kromatografi Lapis Tipis menunjukkan bahwa terdapat senyawa Flavonoid dalam daun Teh Hijau.

\section{DAFTAR PUSTAKA}

1. Fulder S. Khasiat Teh Hijau. Jakarta, 2004.

2. Ibrahim AM, Adijuwana H. Teknik Pemisahan dalam Analisis Biologis. Bogor : Departemen Pendidikan dan Kebudayaan Direktorat Jenderal Pendidikan Tinggi Pusat antar Universitas IImu Hayat Institute Pertanian, 2005.

3. Palevi R. Pemeriksaan Kandungan Flavonoid Daun Benalu Batu Secara Kromatografi Lapis Tipis (Karya Tulis IImiah). Palu : Akademi Farmasi Tadulako Farma, 2005. 